\title{
Bacterial translocation - impact on the adipocyte compartment
}

\section{Tassilo Kruis, Arvind Batra and Britta Siegmund *}

Department of Medicine I (Gastroenterology, Rheumatology, Infectious Diseases), Charité - Universitätsmedizin Berlin, Berlin, Germany

\section{Edited by:}

Anna Katrina Walduck, RMIT

University, Australia

\section{Reviewed by:}

Cecilia Garlanda, Istituto Clinico

Humanitas, Italy

Volkhard A. J. Kempf, Hospital of the

Goethe University Frankfurt am Main,

Germany

\section{${ }^{*}$ Correspondence:}

Britta Siegmund, Department of

Medicine I (Gastroenterology,

Rheumatology, Infectious Diseases),

Charité - Universitätsmedizin Berlin,

Campus Benjamin Franklin,

Hindenburgdamm 30, Berlin 12200,

Germany

e-mail: britta.siegmund@charite.de
Over the last decade it became broadly recognized that adipokines and thus the fat tissue compartment exert a regulatory function on the immune system. Our own group described the pro-inflammatory function of the adipokine leptin within intestinal inflammation in a variety of animal models. Following-up on this initial work, the aim was to reveal stimuli and mechanisms involved in the activation of the fat tissue compartment and the subsequent release of adipokines and other mediators paralleled by the infiltration of immune cells. This review will summarize the current literature on the possible role of the mesenteric fat tissue in intestinal inflammation with a focus on Crohn's disease (CD). CD is of particular interest in this context since the transmural intestinal inflammation has been associated with a characteristic hypertrophy of the mesenteric fat, a phenomenon called "creeping fat." The review will address three consecutive questions: (i) What is inducing adipocyte activation, (ii) which factors are released after activation and what are the consequences for the local fat tissue compartment and infiltrating cells; (iii) do the answers generated before allow for an explanation of the role of the mesenteric fat tissue within intestinal inflammation? With this review we will provide a working model indicating a close interaction in between bacterial translocation, activation of the adipocytes, and subsequent direction of the infiltrating immune cells. In summary, the models system mesenteric fat indicates a unique way how adipocytes can directly interact with the immune system.

Keywords: Crohn's disease, mesenteric fat, innate receptors, adipokines, bacterial translocation

\section{WORKING MODEL}

\section{WHAT IS INDUCING ADIPOCYTE ACTIVATION?}

Classically, adipose tissue was categorized as the site of energy storage and release. But this concept changed profoundly within the last decades when adipose tissue has been identified as a potent endocrine organ with effects on metabolism and immunity. Fat tissue is a powerful producer of fatty acids, classical cytokines, chemokines, and adipokines, to name just some of the factors released. Considering that adipose tissue accounts for $10-20 \%$ of the body weight in males and $20-30 \%$ in females (1) one can well accept that this endocrine tissue has been studied more closely for its impact on body homeostasis and immune cell regulation.

Adipose tissue comprises not only mature adipocytes but harbors a variety of other cells including adipocyte precursor cells (preadipocytes), fibroblasts, and immune cells including $\mathrm{T}$ cells and macrophages. The size of adipocytes varies according to their lipid content and is linked to the function of the cells, with larger adipocytes usually being more active with regard to their metabolic activity and adipokine production (2). In mammals two kinds of adipose tissue exist. Brown adipose tissue plays an important role in thermogenesis in particular in neonates whereas the main adipose tissue present in adults belongs to the white adipose tissue. Hence this review will focus on white adipose tissue, which is distributed throughout the body mainly at two different sites, the subcutaneous and the visceral compartment. Subcutaneous fat is present as hypodermis under the skin and visceral adipose tissue surrounds organs in the abdominal cavity. Both compartments exert different competence with regard to metabolic and immune regulating function with the increase in metabolic diseases in particular being linked to the visceral fat (3). The visceral fat can be subdivided into omental fat which surrounds the intestine superficially, retroperitoneal fat near the kidney and the mesenteric fat in close proximity to the intestine (4).

In Crohn's disease (CD), a specific hypertrophy of the mesenteric fat adjacent to the inflamed intestinal segments occurs. Burrill J. Crohn himself reported in the thirties of the last century, that mesenteric fat is increased and closely attached to inflamed parts of the colon and termed this observation "creeping fat," an alteration unique to $C D$ patients. Since then this initial report was verified by different techniques and groups over the last years (57). $\mathrm{CD}$ is a chronic intestinal inflammation that mainly affects the terminal ileum and the proximal large bowel, but can potentially involve any location of the alimentary tract. The etiology of the disease is not finally understood, and current therapeutic strategies are not curative, although they are effective in alleviating clinical symptoms.

But even though the close contact of creeping fat and inflamed intestinal segments in $\mathrm{CD}$ has been known for decades, the role of this fat hypertrophy and the consequences of this local adipose tissue increase for the ongoing intestinal inflammation are not understood yet (8). With the perception regarding the multiple functions of adipose tissue changing in the recent years, the interest in deciphering the link between the mesenteric fat hypertrophy in patients and the intestinal inflammation arose. Even though the 
interaction between the sites is still not completely understood, there is solid evidence, that they affect each other.

It is not known during which stage of disease the mesenteric fat hypertrophy develops, but one underlying cause expected to be related to the local adipose tissue remodeling is the altered intestinal barrier function and subsequent bacterial translocation. In $\mathrm{CD}$, as well as in experimental models of intestinal inflammation, such increased translocation of bacteria into the intestinal fat occurs. This finding is already leading to our first questions: how does inflammation arise in mesenteric adipose tissue in the setting of CD?

Bacterial translocation represents a possible mechanism as altered epithelial permeability is a feature of CD disease and bacteria are more frequently present in both mesenteric adipose tissue and mesenteric lymph nodes of $\operatorname{CD}$ patients $(9,10)$. Similarly, in experimental models of inflammatory bowel disease (IBD) such as dextran sulfate sodium (DSS)-induced colitis or indometacin-induced ileitis bacterial translocation was enhanced $(10,11)$.

But one has to bear in mind that bacterial translocation is not unique to states of intestinal inflammation, however it is increased when compared to healthy subjects where bacterial translocation to mesenteric adipose tissue can equally be detected (10).

Concerning the mechanisms leading to increased permeability in intestinal inflammation several factors are discussed for bacteria. First, the intestinal barrier consists of the secreted mucus barrier as well as the cellular barrier (12). The barrier formed by mucus and here in particular the dysregulation of defensin production plays a critical role in CD (13-15). Thus targeting alterations in the composition of these anti-microbial peptides might serve as therapeutic strategy in the future (16).

In addition, defects in the cellular barrier have been reported. Söderholm and colleagues detected augmented tight junction permeability in the intestine of CD patients (17). Zeissig and colleagues linked changes in the expression of claudins 2, 5, and 8 to reduced strands of tight junctions in active disease accompanied by an increased rate of epithelial cell apoptosis in active CD (18). While the increased incidence of bacterial translocation in $\mathrm{CD}$ patients is commonly accepted, the mechanisms allowing for bacterial translocation are not finally dissected. In fact, the underlying mechanisms might even be different in ileal and colonic CD, as depicted in detail by Gersemann and colleagues in a recent review (16). Leading us to the question what might be the consequence of increased bacterial translocation into the adjacent adipose tissue?

Besides their energy storing capacity and their secretory activity, adipocytes share commonalities with immune cells. An initial link between adipocytes and innate immunity was a report, that depicted the plasticity of murine preadipocytes which could convert to macrophage-like cells, characterized by the expression of macrophage markers like F4/80 and Mac-1 as well as costimulatory molecules including CD80 and CD86 (19). In the meantime further similarities have been revealed. For instance, macrophages, preadipocytes, and adipocytes express different classes of pattern recognition receptors enabling them to respond to microbial moieties with either increased or decreased secretion of immunological active molecules $(11,20,21)$.

\section{Adipose tissue responsiveness to endotoxin}

Already in the seventies of the last century it was shown that adipose tissue is responsive to bacterial compounds such as endotoxin as assessed by alterations in lipid metabolism in rodents following injection of this bacterial antigen with differences in the grade of lipolysis between subcutaneous and mesenteric fat (22-24). This sensitivity of fat toward bacterial components was well studied during the following decades, but again with an emphasis on the effects on metabolism $(25,26)$.

Taking into account that the availability of energy is a prerequisite for immune function, in the following years the consequences of adipose tissue stimulation by bacterial products for the immune system were studied. Local LPS application induced the release of glycerol from adipose tissue surrounding lymph nodes, thus supporting the initiation of the immune response and linking the capacity of adipose tissue to detect bacterial products $(27,28)$. Again, these studies mainly focused on the biological effects of stimulation and not on the mode of antigen recognition involved.

\section{Toll-like receptors}

In 2000 Lin and coworkers demonstrated that adipocytes express Toll-like receptors (TLR) (29), a group of transmembrane receptors that sense highly conserved microbe-associated molecular patterns (30).

So far a total of 13 TLR have been identified, with 10 and 12 functional in humans and mice (31). These receptors recognize conserved structures that are not present in the host, but more or less frequently present in viruses, fungi, or bacteria and include for example zymosan, flagellin, nucleic acids, and LPS (32).

Stimulation of these innate receptors by their specific ligands is followed by the activation of signaling pathways such as nuclear-factor kappaB (NFkB) or mitogen-activated protein kinase (MAPK), resulting in the production of pro-inflammatory cytokines in immune cells (33). Lin and colleagues described not only the expression of TLR on adipocytes and preadipocytes but further revealed that the activation of TLR4 resulted in an increase of TLR2 expression in adipocytes, already suggesting that the response to bacterial products is well orchestrated in these cells (29).

Further studies confirmed that adipocytes and preadipocytes express numerous receptors from the TLR family. We and others have provided evidence for the functional expression of TLRs on adipocytes and preadipocytes. For example stimulation of TLR4 in adipocytes and preadipocytes by LPS induced increased production of classical cytokines and chemokines including IL-6, MCP-1, and $\mathrm{TNF} \alpha(34-36)$.

When characterizing TLR expression and responsiveness, our group revealed that leptin deficiency, an adipokine initially described as a satiety signal, altered TLR expression and cytokine release following stimulation (35). This observation was confirmed by Kim and colleagues who reported an increased TLR expression not only in leptin-deficient mice, but equally in mice fed a high-fat diet (37). This link between leptin and TLR expression could be confirmed in human cells where expression of TLR2 on monocytes is enhanced in the presence of high levels of leptin. An effect, that might contribute to the increased immune response seen in obesity (38). Furthermore, this observation is bridging the 
energy status of the organism to the initial concept, that responsiveness of adipose tissue to bacterial antigens is linked to the regulation of energy supply.

In fact the interplay of energy supply or nutrition and TLR expression in adipocytes forms a subject of recent research in the field of metabolic diseases. For example supply of citrus flavonoid is not only beneficial in obesity-related diseases but was furthermore linked to its' modulating effects on TLR2 expression (39). Bearing such mutual interactions between energy supply and TLR expression in mind it seemed a logical consequence to ask whether pathogen-associated molecular patterns present the sole ligands for TLR?

One group reported in 2009, that at least TLR4 on adipocytes can be stimulated directly by fatty acids leading to the activation of NF- $\mathrm{B}$ with different fatty acids inducing specific profiles of released adipokines (40). Indeed it was an intriguing thought, that in altered states of fatty acid release by the adipose depot, i.e. in various states of nutritional supply, the TLR signaling pathway is involved in the modulation of the endocrine activity of the fat tissue compartment. However, in 2009 this view was negated by Erridge and Samani who pointed out that these studies dealing with TLR4-specific stimulation following supply of fatty acids in vitro might be hampered by LPS contamination of the fatty acids employed or the proteins used for solving them, thus questioning direct effects of the fatty acids on TLR stimulation (41). This later view is supported by a study that investigated fatty acid effects on TLR activation where no direct stimulation of TLR2 and TLR4 by dietary saturated and unsaturated fatty acids was measured (42).

Not only the direct effect of altered fatty acid levels in adipose tissue in the course of diet or infection on TLR has not been deciphered yet. Conflicting reports about the link between the nutritional status and the TLR expression exist. While recently one report stated that mRNA levels of TLR2, TLR6, and TLR7 are decreased in mice fed a high-fat diet (43), other studies provide evidence that TLR1-9 and TLR11-13 are up-regulated in murine adipose tissue following obesity-induction by a high-fat diet (37). Thus deciphering the impact of TLR expression on the function of adipose tissue cells is still a field full of open questions that requires further clarification. However, there is an additional class of receptors present in adipocytes that further supports their commitment to the innate immune system, the so-called nucleotide-binding oligomerization domain (NOD)-like receptors.

\section{The nucleotide-binding oligomerization domain-like receptors}

Like TLR, NOD-like receptors detect highly conserved non-self antigens. This group comprises the subfamilies of NOD, NLR family pyrin-domain-containing proteins (NLRP), NLR family CARD-domain containing (NLRC), neuronal apoptosis inhibitor factors (NAIP), NLRX, and MHC II transactivator (CIITA), with all of these receptors being localized in the cytosol $(32,44)$. NOD1 and NOD2 were the first members of the NLR family to be described and are responsive to subunits of peptidoglycans $(45,46)$. In CD these receptors gained particular interest, since polymorphisms in NOD2 were linked to an increased risk of developing CD $(47,48)$. Our group was the first to show that preadipocytes express not only NOD1 and NOD2 receptor specific mRNA but functional cytosolic receptors (20). Since then, several groups confirmed the presence of functional NOD receptors in fat cells from mice and man and postulated both, effects on immune response and insulin sensitivity as a consequence of stimulation $(49,50)$.

A recent study depicts that NOD activation is linked to adipocyte differentiation. In a murine cell line differentiation of preadipocytes to mature adipocytes was decreased by NOD1- but not NOD2-specific stimulation. The authors noticed some species specific differences when they tested this observation in human cells where activation of either of the two receptors, NOD1 or NOD2, suppressed maturation of adipose tissue derived stem cells to adipocytes (51).

Even though it is well accepted that genetic variants of NOD2 are associated with a higher susceptibility to CD (52) the consequence of NOD2 stimulation by bacterial products is not finally understood. Our own group noticed regulation of NOD2 mRNA in preadipocytes following stimulation of NOD1 or via proinflammatory cytokines. But unlike stimulation of NOD1 no induction of cytokine release took place thereafter (20). This is in line with the current concept, that NOD2 activation might be a regulator of TLR-induced cytokine production. For example in human dendritic cells loss of functional NOD2 results in an increased IL-23 production induced by stimulation with $E$. coli (53). In a study published this year, the effect of the NOD2 variants on bacterial translocation was characterized in patients. As compared to controls bacterial mRNA was more frequent in the blood of patients carrying either a NOD2- or an ATG16L1-variant genotype. In addition, the presence of bacterial DNA was related to disease activity and in patients with NOD2 variants the phagocytic and bactericidal activity of blood neutrophils was decreased (54). Even though this study omitted any information about mesenteric adipose tissue it is tempting to speculate that variants of CD susceptibility genes might alter responses therein to bacterial products. But what mechanisms can be activated in adipocytes following the stimulation of the innate receptors? As mentioned before, adipose tissue is the source of a plethora of mediators which will be presented together with information about the biological consequences of the release in the next section.

\section{WHICH FACTORS ARE RELEASED BY ADIPOCYTES AFTER ACTIVATION AND WHAT ARE THE CONSEOUENCES FOR THE LOCAL FAT TISSUE AND MACROPHAGES COMPARTMENT}

The infiltration of mesenteric adipose tissue by macrophages was initially described in murine models of obesity $(55,56)$, an observation subsequently confirmed in humans $(57,58)$. About $30 \%$ of transcripts in mesenteric adipose tissue that correlated strongest with obesity were inflammatory or macrophage specific (55). The infiltration of macrophages into the inflamed mesenteric adipose tissue represents a cardinal feature of creeping fat in $\mathrm{CD}$ (59). Although fat wrapping is not typically observed in animal models of colitis, macrophage infiltration of mesenteric adipose tissue contiguous to sites of intestinal inflammation has been described $(60,61)$.

Activation of the mesenteric adipose tissue results in the release of cytokines (e.g., IL-6, TNF $\alpha$ ), chemokines (e.g., MCP-1/CCL2, Rantes/CCL5), adipokines (e.g., leptin, adiponectin, resistin, visfatin), but also fatty acids (26, 62-64). Furthermore, preadipocytes 
have the potential to differentiate into macrophage-like cells that express macrophage markers like F4/80, Mac-1, CD80, or CD86, and are capable to phagocytose microorganisms (19). In mesenteric adipose tissue of patients with CD a variety of such potent molecules can be detected $(59,65-67)$ thereby influencing macrophage recruitment and polarization.

In parallel to T helper cells the concept of macrophage polarization to either classically activated M1 macrophages or alternatively activated M2 macrophages was established. M1 macrophages produce pro-inflammatory cytokines such as IL-1 $\beta$, IL-6, and TNF $\alpha$, as well as effector molecules including reactive oxygen species or nitric oxide. In contrast, M2 macrophages express high amounts of IL-10, scavenger-, mannose-, and galactose-type receptors, are involved in Th2 cell activation and regulate extracellular matrix molecule synthesis, wound repair, and tumor progression. However, it is well accepted that in vitro generated M1 or M2 macrophages represent extreme states on a continuum with tissue macrophages displaying phenotypes comprising hallmarks of both (68-70). Adipose tissue macrophages are characterized by the expression of M2 surface markers like CD163, CD206, CD209, and CD200, a high phagocytic activity, and the secretion of IL-10 and IL-1 receptor antagonist (IL-1Ra). They release pro-inflammatory molecules including TNF $\alpha$, IL-6, IL-1, MCP-1, and MIP- $1 \alpha$ in quantities higher than in vitro generated M1 macrophages. These macrophages cluster around necrotic adipocytes indicating a functional role in the clearance of extracellular lipid and cellular debris while they also contribute to adipose tissue inflammation and metabolic dysfunction by inflammatory cytokines $(71,72)$. In obesity the adipose tissue macrophage phenotype is skewed even further toward M1 polarization $(73,74)$, whereas in CD adipose tissue macrophages show an increased expression of M2 markers (75).

In the following, we will discuss molecules that are secreted by activated preadipocytes or adipocytes under inflammatory conditions with the potential to recruit macrophages and modulate their phenotype or function. If LPS was used as an activating stimulus, it was derived from E. coli.

\section{IL-6 and TNF $\alpha$}

Both IL- 6 and TNF $\alpha$ are key players in inflammation and their role in the pathophysiology of CD is well established. IL-6 serum levels correlate with disease severity and localization (76). Estimated $10-30 \%$ of circulating IL-6 is released from adipose tissue (77). Increased TNF $\alpha$ levels have been observed in serum and intestine of CD patients, more important, neutralizing $\mathrm{TNF} \alpha$ represents an approved treatment (78-81). Both IL-6 and TNF $\alpha$ are released by preadipocytes and adipocytes upon stimulation with LPS (62, 63). Regarding IL-6, its expression is increased in the mesenteric adipose tissue in TNBS colitis and inflammation is accompanied by macrophage infiltration $(60,61)$. However, in inflamed mesenteric adipose tissue of CD patients IL-6 expression seems not to be significantly higher than in other inflammatory conditions like colorectal cancer (CC) or diverticulitis $(67,82)$.

IL-6 exerts direct chemotactic effects on monocytes by inducing integrin expression, cell attachment, and transmigration through the endothelium (83-85). Whether IL-6 itself modulates macrophage phenotype and function is not reported yet. But in preliminary studies we observed that at least in vitro the presence of IL-6 directs macrophages to an anti-inflammatory phenotype characterized by expression of CD163 and release of IL-10 (unpublished data). However, IL-6 might influence the polarization of adipose tissue macrophages via regulation of adipokine secretion. For example, IL-6 in combination with soluble IL-6 receptor inhibits adiponectin expression in 3T3-L1 adipocytes and primary human adipocytes. Similarly, TNF $\alpha$ down-regulates adiponectin secretion paralleled by an increase in leptin expression (86-88). The impact of $\mathrm{TNF} \alpha$ signaling on macrophage polarization is supported by studies in TNF-receptor 1 (TNFR1) and TNFR2 deficient mice. On a high-fat diet, they show increased weight gain and adipose tissue macrophage infiltration. Surprisingly, the expression of pro-inflammatory cytokines like IL-6 and MCP-1 is reduced paralleled by a skew of adipose tissue macrophages from M1 to M2 polarization (89).

A further indirect evidence that $\mathrm{TNF} \alpha$ is of significance for macrophage polarization is the observation that the anti$\mathrm{TNF} \alpha$ antibodies infliximab and adalimumab induce M2-like macrophages in a mixed lymphocyte reaction. These cells inhibit T-cell proliferation, secrete IL-10, and display an up-regulation of the M2 marker CD206. However, the observed effect is probably not only mediated by neutralizing TNF $\alpha$ but also by Fc $\gamma$-receptor mediated binding of TNF $\alpha$-antibody complexes (90).

\section{C-reactive protein}

The acute phase reactant C-reactive protein (CRP) is widely used in clinical routine as a biomarker of inflammation in both infectious and autoimmune diseases. In CD serum CRP levels do not only indicate acute inflammation but also have predictive value regarding the course of disease (91). While liver is considered to be the main source of CRP (92) evidence is mounting that adipose tissue is another important source. Circulating CRP levels increase with BMI in obese patients (93) while in CD CRP levels correlate with mesenteric fat density measured by CT enterography (5). Recently, elevated CRP expression was demonstrated within mesenteric adipose tissue of $\mathrm{CD}$ patients compared to healthy controls and patients with ulcerative colitis (UC). Adipose tissue expression and plasma levels correlated indicating that adipose tissue might be an important source of total circulating CRP. Interestingly, this elevated CRP expression was paralleled by increased bacterial translocation to mesenteric adipose tissue and lymph nodes. In vitro, adipocytes release CRP after stimulation with TNF $\alpha$, IL-6, LPS, and E. coli, but not Pam3Cys (a TLR2 ligand), MDP (a NOD2 ligand) or Lactobacillus spp. Thus, local cytokines and translocalized gram-negative bacteria may synergize to promote CRP expression in mesenteric adipose tissue $(10,93)$.

C-reactive protein binds to cell wall components of different bacteria, damaged cells, and nuclear autoantigens. In consequence, the classical complement cascade is activated leading to opsonization of the bound antigens. Furthermore, CRP itself binds to Fc $\gamma$-receptors on immune cells like monocytes and macrophages (92). Regarding its effect on monocytes and macrophages conflicting results were published. It was reported that CRP in synergy with LPS induces both pro-inflammatory and anti-inflammatory cytokines like IL-1 $\beta$, IL-6, TNF $\alpha$ (94), and IL-1Ra in human monocytes $(95,96)$. For human alveolar macrophages both stimulatory 
and inhibitory effects of CRP on the release of IL- $1 \alpha$, IL- $1 \beta$, $\mathrm{TNF} \alpha$, and IL-1Ra were described $(95,97)$. Incubation of human monocyte-derived macrophages or isolated rat macrophages with human CRP followed by LPS stimulation resulted in a decreased IL-10 secretion (98), whereas in mice treatment of macrophages with human CRP induced IL-10 production (99). This might be due to species differences in the role of CRP as an acute phase reactant.

Regarding macrophage polarization, incubation of human monocytes with CRP for 7 days resulted in pro-inflammatory macrophages characterized by a high expression of TNF $\alpha$, IL-12, CCR2, MCP-1, and IL-1. In parallel less cells expressed M2 markers like CD206, CD163, and IL-10 even if primed before with IL-4 (100). On the contrary, it was described that CRP treatment of human monocyte-derived macrophages induced M-CSF release, a factor well known to polarize macrophages to an M2 phenotype (101). These discrepancies will have to be addressed in the future.

\section{MCP-1 and RANTES}

RANTES/CCL5 and MCP-1/CCL2 are both chemokines secreted from preadipocytes or adipocytes upon stimulation with LPS (62-64). Whereas RANTES/CCL5 is up-regulated in mesenteric adipose tissue of CD, MCP-1 is elevated in tissue from obese patients $(66,67,102)$.

MCP-1 is an important macrophage chemoattractant in several inflammatory conditions and various tissues $(103,104)$. Evidence in the literature suggests that MCP-1 and its receptor CCR2 are relevant factors for macrophage recruitment and accumulation in inflamed adipose tissue. For instance, genetic ablation of MCP-1 or its receptor resulted in a decrease in obesity-induced adipose tissue inflammation and macrophage infiltration, the opposite was observed for MCP-1 over-expression (105-107). However, data on this topic are conflicting as other reports did not describe such an effect in MCP-1 knock-out mice arguing that MCP1 is at least not critical for macrophage infiltration to adipose tissue $(108,109)$.

In murine tumor models blockage of MCP-1 does not affect overall tumor associated macrophage number, but results in a skew of macrophage phenotype with reduced expression of M2 markers (CD206 and arginase 1) and slight up-regulation of the M1 marker inducible nitric oxide synthase (iNOS) (110). Together with IL6, MCP-1 favors survival of human $\mathrm{CD} 11 \mathrm{~b}^{+}$peripheral blood mononuclear cells (PBMC) and augments CD206 expression as well as the total number of $\mathrm{CD} 14^{+} / \mathrm{CD} 206^{+}$cells an effect mediated via inhibition of caspase- 8 cleavage and enhanced autophagy (111). Besides MCP-1, RANTES and its receptor CCR5 may be involved in adipose tissue macrophage recruitment and polarization. For example, CCR5 knock-out mice display reduced numbers of adipose tissue macrophages accompanied by a skew toward an M2 phenotype (112).

\section{M-CSF and GM-CSF}

M-CSF is expressed significantly higher in mesenteric adipose tissue from patients with CD compared to diverticular disease and $\mathrm{CC}$ and its over-expression is associated with adipocyte hypertrophy $(67,113)$. Studies applying M-CSF knock-out mice indicate its importance for normal macrophage differentiation in various tissues (114). Regarding macrophage polarization, highly pure subsets of anti-inflammatory M2 macrophages can be obtained by differentiating human mononuclear cells in the presence of M-CSF (115). These cells stably express CD163 and IL-10 as a signature cytokine even in presence of strong co-stimuli such as IFN $\gamma$ or CD40L. They release only relatively low amounts of pro-inflammatory cytokines like TNF $\alpha$, IL-1 $\beta$, IL-6, and fail to secrete IL-12/IL-23 $(115,116)$. This is accompanied by a slower $\mathrm{I} \kappa \mathrm{B} \alpha$ degradation and recruitment of $\mathrm{NF} \kappa \mathrm{B}$ to its nuclear binding sites (117).

At least in vitro, opposite effects can be observed for GM-CSF polarizing human macrophages toward an M1 phenotype (115118). Both M-CSF and GM-CSF seem to act as opponents on human macrophage function as they suppress the cellular response of each other when added to the same monocyte/macrophage population $(119,120)$. Whether GM-CSF expression is altered in mesenteric adipose tissue in $\mathrm{CD}$ has not been investigated yet. In murine obesity models, GM-CSF seems to be relevant for macrophage recruitment to mesenteric adipose tissue where it is highly expressed. GM-CSF knock-out mice display reduced numbers of adipose tissue macrophages accompanied by lower levels of pro-inflammatory cytokines (121). Thus, the local M-CSF/GMCSF ratio might be a factor modulating macrophage polarization during inflammation. A high local expression of M-CSF might add to the enrichment of $\mathrm{CD} 163^{+} \mathrm{M} 2$ macrophages observed in the creeping fat of CD (75).

\section{Leptin, adiponectin, resistin, and visfatin}

The adipokine leptin is up-regulated in the mesenteric adipose tissue of CD and UC patients compared to CC and diverticular disease $(65,67)$. In contrast to other adipokines like adiponectin, resistin, and visfatin, which are all down-regulated leptin expression is not affected or even enhanced in long term LPS-activated adipocytes (64). Leptin seems to have direct effects on intestinal barrier function. Increased levels affect mucin production and increase colonic tight junction permeability (122-124). Furthermore it promotes growth of colonic epithelial cells (125). All these factors contribute to the integrity of the intestinal barrier hence leptin deficiency results in an increased bacterial translocation to the blood (126). Regarding its effects on monocytes and macrophages, leptin promotes phagocytosis and release of proinflammatory cytokines (e.g., IL-6, TNF $\alpha$ ) and reactive oxygen species (127-129). Furthermore, it activates vascular endothelial cells resulting in up-regulation of adhesion molecules thereby facilitating diapedesis of monocytes (130). Data from our group and others indicate that leptin also modulates macrophage polarization. Culturing human monocytes in the presence of leptin results in an increase in the expression of the M2 surface markers CD14, CD206, and CD209 accompanied by relatively high expression of TNF $\alpha$, IL-6, IL-1 $\beta$, and IL-10 (131). Similarly, we observed an increased secretion of TNF $\alpha$, IL-6, and IL-10 after leptin stimulation of in vitro generated M1 and M2 macrophages using GM-CSF or M-CSF, respectively. This was paralleled by an enhanced phagocytic and chemotactic capacity (75). Besides, leptin induces GM-CSF secretion at least in murine peritoneal macrophages that might affect their polarization in an autocrine manner (128). Taken together, leptin effects could contribute to 


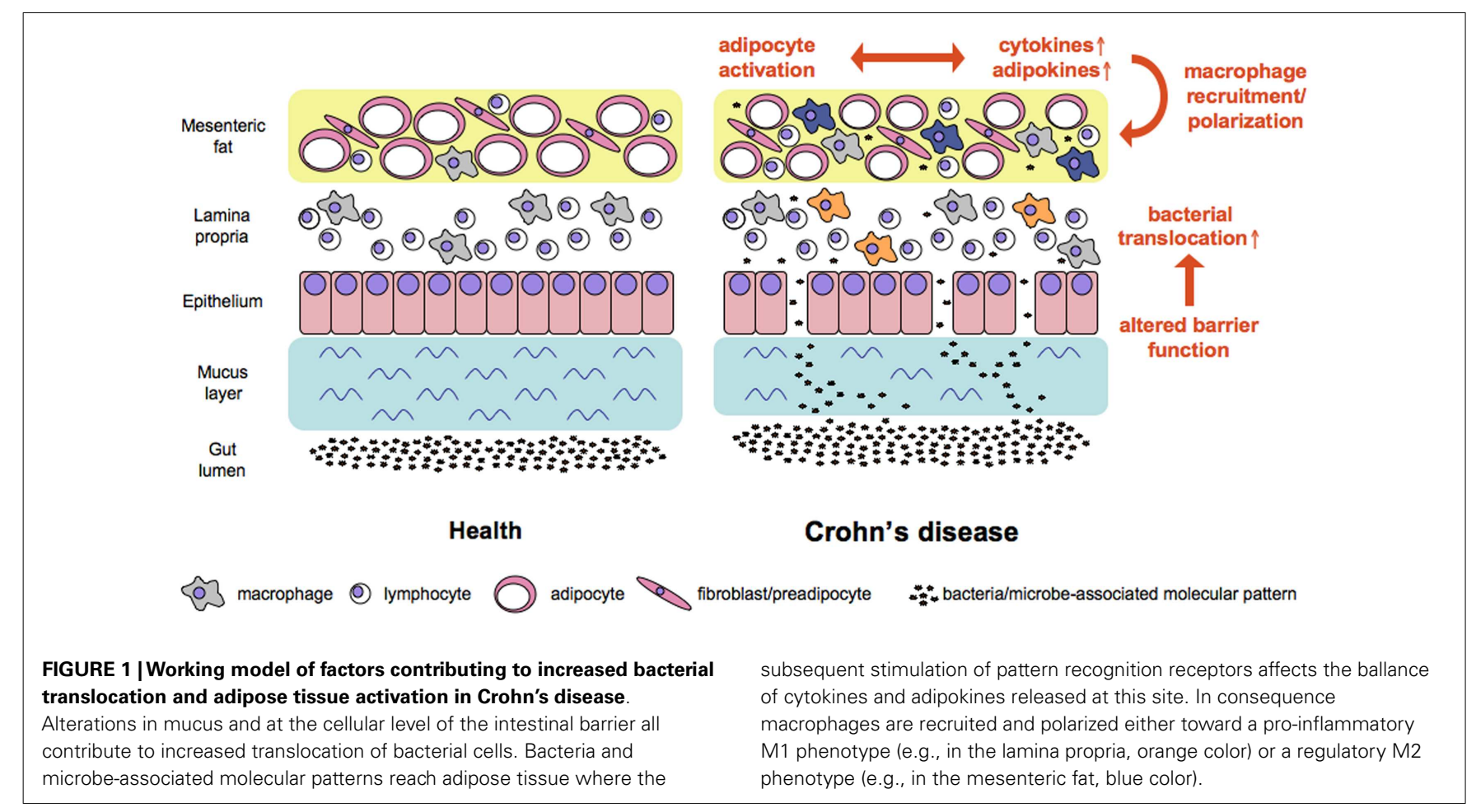

the particular phenotype of adipose tissue macrophages displaying hallmarks of both M1 and M2 polarization (72).

Adiponectin belongs to C1q/TNF molecular superfamily and shares structural similarities with $\mathrm{TNF} \alpha, \mathrm{TNF} \beta$, and CD40L (132, 133). Yamamoto et al. reported that adiponectin expression was significantly increased in the creeping fat of patients with CD nearby inflamed intestine (134). Similarly, Paul et al. detected increased adiponectin expression in CD creeping fat (67). In vitro adiponectin expression is not altered in mature adipocytes stimulated by LPS. However, differentiation of preadipocytes to adipocytes is inhibited with a consecutive reduction in adiponectin expression (64). The effect of adiponectin on macrophages seems to be anti-inflammatory as it suppresses LPS induced TNF $\alpha$ and IL- 6 release, increases IL-10 secretion and impairs the phagocytic capacity $(135,136)$. Adiponectin inhibits several pro-inflammatory pathways elicited by LPS, TNF $\alpha$, and IL-6 in human macrophages via the induction of anti-inflammatory proteins (137). In creeping fat adiponectin levels correlated negatively with IL-6 and CRP expression (134). Opposite to leptin (130), adiponectin inhibits TNF $\alpha$ induced up-regulation of adhesion molecules like VCAM-1, ICAM-1, and E-selectin on vascular endothelial cells thereby preventing monocytes from attachment $(138,139)$.

Several studies investigated the modulating effects of adiponectin on macrophage polarization but with contradictory results. Adiponectin has been identified to induce M2 markers such as CD163, CD206, and CCL18 in both murine and human macrophages $(140,141)$. In RAW264.7 macrophages, adiponectin led to an M2 phenotype via an IL-4 dependent manner (142). In contrast to these data, the analysis of an adiponectin-induced transcriptome in human mononuclear cell-derived macrophages showed an augmented expression of 28 of 46 strictly M1associated markers, whereas only 3 of 43 M2-associated markers were increased (143). In the latter study both M1 cytokines like TNF $\alpha$ and IL- 6 and M2 cytokines such as CCL18 and CCL23 were induced. Data from our group indicate that adiponectin alters the phenotype and function of M1 and M2 macrophages differentiated with either GM-CSF or M-CSF, respectively, with the M2 phenotype being more susceptible. Adiponectin up-regulates IL-10, IL-6, TNF $\alpha$, and CD206 expression in M2 macrophages thus leading to cells comprising both pro- and anti-inflammatory potency as described for adipose tissue macrophages (75).

Circulating resistin levels are increased in $\operatorname{IBD}(144,145)$. Increased resistin expression was found in the mesenteric adipose tissue of patients operated on $\mathrm{CD}$ and diverticulitis but not CC (67). In human adipose tissue, resistin expression is 2.5 times higher in the omental than in subcutaneous fat with nonfat cells being its main source $(146,147)$. In human PBMC and macrophages, resistin expression can be induced by different stimuli such as TNF- $\alpha$, IL-1, IL-6, and LPS $(148,149)$. But also LPS stimulation of isolated human subcutaneous adipocytes results in increased resistin expression (150). Furthermore, experimental endotoxemia causes a strong rise in circulating resistin levels (149). Resistin itself induces the secretion of pro-inflammatory cytokines such as IL-1 $\beta$, IL-6, IL-12, and TNF $\alpha$ in human PBMC and macrophages $(151,152)$. Furthermore, it up-regulates adhesion molecules like ICAM-1 and VCAM-1 as well as MCP-1 in human endothelial cells facilitating monocyte recruitment (153). However, whether resistin directly modulates macrophage polarization has not been investigated to our knowledge.

Visfatin is an adipokine preferentially expressed in visceral adipose tissue (154). Its circulating levels are increased in IBD 
Table 1 | Summarizes alterations in CD adipose tissue as outlined in this review and provides a simplified working model to visualize adipose tissue alterations in CD as compared to normal fat and the state of obesity.

\section{Normal adipose tissue}

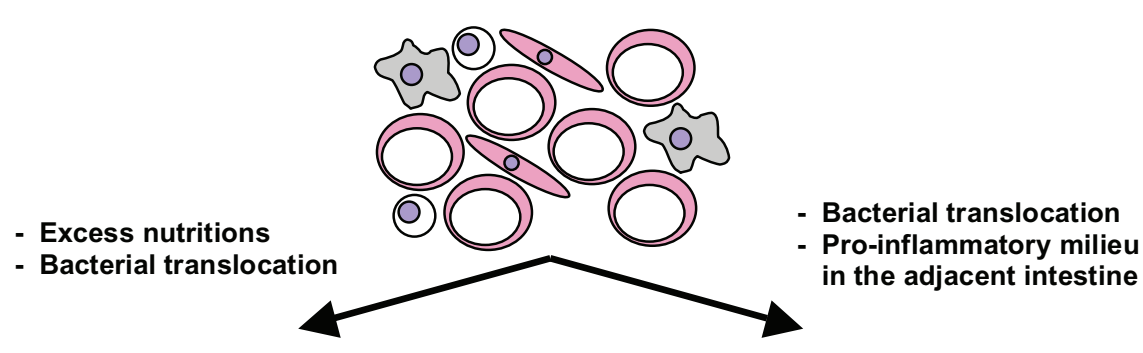

Obesity

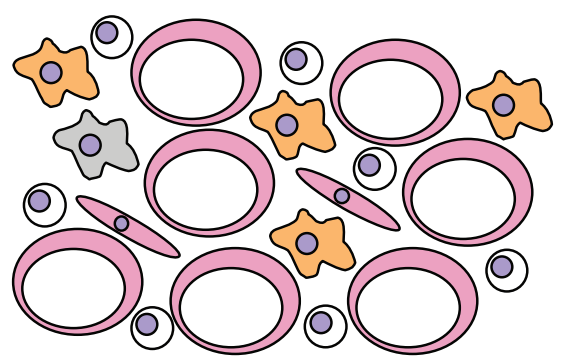

Cellular alterations

Mediators released

Legend

CD mesenteric fat

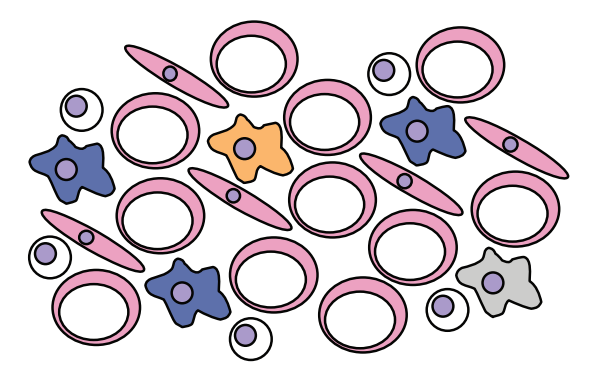

Adipocyte size

Adipocyte number

Local immune cells

M1 macrophages

M2 macrophages

$$
\begin{gathered}
\text { IL-6 } \\
\text { TNF } \alpha \\
\text { MCP-1 } \\
\text { M-CSF } \\
\text { Leptin } \\
\text { Adiponectin } \\
\text { Resistin } \\
\text { Visfatin } \\
\text { C-reactive protein } \\
\text { RANTES } \\
\text { Free fatty acids } \\
\text { Fetuin A }
\end{gathered}
$$

Regulatory macrophage M2

Fibroblast/preadipocyte

$\uparrow \downarrow$, increase or decrease as compared to fat from healthy controls; -, no alteration reported; n.d., not done.

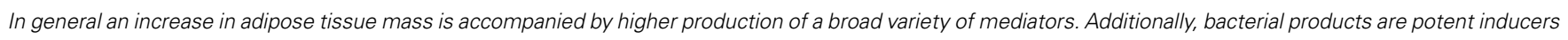

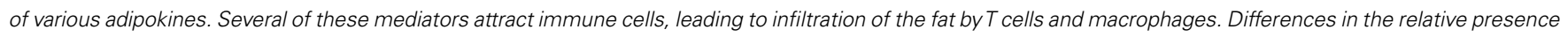

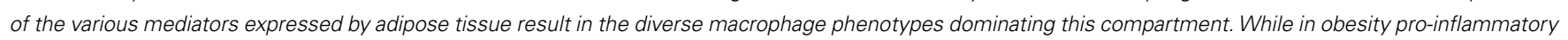
$\mathrm{M} 1$ cells accumulate, in the mesenteric fat of CD anti-inflammatory M2 macrophages increase.

positively correlating with disease activity $(145,155,156)$ but also in other inflammatory conditions such as acute lung injury (157), atherosclerosis (158), and rheumatoid arthritis (159). In colonic biopsy specimens of IBD patients, adipocytes as well as $\mathrm{CD} 63^{+}$macrophages from both submucosa and mesenteric adipose tissue were identified as cellular sources of visfatin. In human $\mathrm{CD}_{14}{ }^{+}$monocytes, visfatin induced both pro- and antiinflammatory cytokines including IL- $1 \beta$, IL- 6, TNF $\alpha$, IL-1Ra, and IL-10, respectively. In GM-CSF differentiated macrophages however it induces only IL-6. Co-stimulatory molecules like CD80 
and CD40 were up-regulated in visfatin stimulated monocytes leading to an increased stimulatory capacity in a mixed lymphocyte reaction. Furthermore, visfatin enhanced CD206 mediated phagocytosis in human monocytes and appeared to be a potent chemotactic factor for them (155). Thus one may consider visfatin a potent activator of human monocytes. Whether visfatin modulates macrophage polarization has not been investigated in detail. Recently, it was reported that peritoneal macrophages of visfatin $^{-/-}$mice showed reduced iNOS expression and NO release after LPS stimulation whereas visfatin treatment of RAW264.7 cells results in an increase of iNOS mRNA and protein expression (160). These finding indicate that visfatin might skew macrophages toward an M1 phenotype.

Very recently, fetuin A has been discovered as a novel adipokine, which could form the link to understand the above discussed conflicting reports concerning the activation of TLR4 by fatty acids. Pal and colleagues assumed that fetuin A is an endogenous ligand through which fatty acids can stimulate TLR4 (161). Fetuin A itself is released from adipocytes in response to excess lipids in an $\mathrm{NF \kappa B}$ dependent manner. Furthermore, it is capable to attract macrophages and skew their phenotype from M2 toward M1 polarization as it is described in obesity $(161,162)$. However, different mechanisms might induce the macrophage phenotype in the creeping fat of CD patients (75).

\section{DO THE ANSWERS GENERATED BEFORE ALLOW FOR AN EXPLANATION OF THE ROLE OF THE MESENTERIC FAT TISSUE WITHIN INTESTINAL INFLAMMATION? - CONSEQUENCES FOR DISEASE}

Adipose tissue is a multi potent organ with immune modulating capacity. In CD the normal state of local adipokine, cytokine and cell networks seems to be imbalanced with increased influx of immune cells and altered, usually increased, expression of immune regulating mediators.

In CD mesenteric fat shows drastic alterations as compared to health with a significant influx of M2-polarized macrophages and decreased adipocytes size. Since most cells present in adipose tissue express innate receptors we assume that the translocation of bacteria and bacterial products that takes place in CD patients is an initial cause for the mesenteric fat alterations. As a consequence of the stimulation via activation of innate receptors the cytokine and adipokine profiles and levels expressed in the mesenteric fat change (see Figure 1). This altered milieu leads to attraction and switch in phenotype of macrophages, an effect that might fuel the local alterations. It might well be that this accumulation of immune cells and their phenotypic conversion represents a protective mechanism of the mesenteric fat to dampen the adjacent inflammation. On the other hand, since pro-inflammatory adipokines are abundant in the tissue another scenario would be, that due to defective response mechanisms following bacterial stimulation the mesenteric fat in $\mathrm{CD}$ patients is not a barrier to protect the body from the ongoing intestinal inflammation but involved in the persistence of the intestinal inflammation by increased release of for example leptin and resistin.

Interestingly, some of the factors produced at higher levels in CD fat are abundantly expressed in obesity as well (see Table 1 for alterations in mediator production as compared to health and obesity). Thus, the unique feature of $\mathrm{CD}$ mesenteric fat cannot be attributed to abundance of single agents or mediators but seems to be a consequence of the altered proportions of the factors presented in this article.

\section{CONCLUDING REMARKS}

With this review we aim to emphasize the critical interaction of the adipose tissue and the immune system. In our view $\mathrm{CD}$ as well as obesity form two representative examples. However, we would like to suggest that this interaction is of vital significance for other conditions.

\section{AUTHOR CONTRIBUTIONS}

Tassilo Kruis, Arvind Batra, and Britta Siegmund developed the structure of the manuscript and contributed equally to the writing part.

\section{ACKNOWLEDGMENTS}

Our experimental work contributing to this article has been supported by the SFB633 and SI-749/6-1 to Britta Siegmund.

\section{REFERENCES}

1. Fruhbeck G. Overview of adipose tissue and its role in obesity and metabolic disorders. Methods Mol Biol (2008) 456:1-22. doi:10.1007/978-1-59745245-8_1

2. Skurk T, Alberti-Huber C, Herder C, Hauner H. Relationship between adipocyte size and adipokine expression and secretion. J Clin Endocrinol Metab (2007) 92(3):1023-33. doi:10.1210/jc.2006-1055

3. Matsuzawa Y. The role of fat topology in the risk of disease. Int J Obes (Lond) (2008) 32(Suppl 7):S83-92. doi:10.1038/ijo.2008.243

4. Wronska A, Kmiec Z. Structural and biochemical characteristics of various white adipose tissue depots. Acta Physiol (Oxf) (2012) 205(2):194-208. doi:10.1111/j.1748-1716.2012.02409.x

5. Colombel JF, Solem CA, Sandborn WJ, Booya F, Loftus EV Jr, Harmsen WS, et al. Quantitative measurement and visual assessment of ileal Crohn's disease activity by computed tomography enterography: correlation with endoscopic severity and C reactive protein. Gut (2006) 55(11):1561-7. doi:10.1136/gut. 2005.084301

6. Golder WA. The “creeping fat sign”-really diagnostic for Crohn's disease? Int J Colorectal Dis (2009) 24(1):1-4. doi:10.1007/s00384-008-0585-y

7. Parmentier-Decrucq E, Duhamel A, Ernst O, Fermont C, Louvet A, VernierMassouille G, et al. Effects of infliximab therapy on abdominal fat and metabolic profile in patients with Crohn's disease. Inflamm Bowel Dis (2009) 15(10):1476-84. doi:10.1002/ibd.20931

8. Siegmund B, Zeitz M. Standards of medical treatment and nutrition in Crohn's disease. Langenbecks Arch Surg (2005) 390(6):503-9. doi:10.1007/s00423-0040498-3

9. Sedman PC, Macfie J, Sagar P, Mitchell CJ, May J, Mancey-Jones B, et al. The prevalence of gut translocation in humans. Gastroenterology (1994) 107(3):643-9. doi:10.1016/0016-5085(94)90110-4

10. Peyrin-Biroulet L, Gonzalez F, Dubuquoy L, Rousseaux C, Dubuquoy C, Decourcelle $\mathrm{C}$, et al. Mesenteric fat as a source of $\mathrm{C}$ reactive protein and as a target for bacterial translocation in Crohn's disease. Gut (2012) 61(1):78-85. doi:10.1136/gutjnl-2011-300370

11. Batra A, Heimesaat MM, Bereswill S, Fischer A, Glauben R, Kunkel D, et al. Mesenteric fat - control site for bacterial translocation in colitis? Mucosal Immunol (2012) 5(5):580-91. doi:10.1038/mi.2012.33

12. McGuckin MA, Eri R, Simms LA, Florin TH, Radford-Smith G. Intestinal barrier dysfunction in inflammatory bowel diseases. Inflamm Bowel Dis (2009) 15(1):100-13. doi:10.1002/ibd.20539

13. Jespersgaard C, Fode P, Dybdahl M, Vind I, Nielsen OH, Csillag C, et al. Alphadefensin DEFA1A3 gene copy number elevation in Danish Crohn's disease patients. Dig Dis Sci (2011) 56(12):3517-24. doi:10.1007/s10620-011-1794-8

14. Wehkamp J, Salzman NH, Porter E, Nuding S, Weichenthal M, Petras RE, et al. Reduced Paneth cell alpha-defensins in ileal Crohn's disease. Proc Natl Acad Sci U S A (2005) 102(50):18129-34. doi:10.1073/pnas.0505256102 
15. Zilbauer M, Jenke A, Wenzel G, Postberg J, Heusch A, Phillips AD, et al. Expression of human beta-defensins in children with chronic inflammatory bowel disease. PLoS One (2010) 5(10):e15389. doi:10.1371/journal.pone.0015389

16. Gersemann M, Wehkamp J, Stange EF. Innate immune dysfunction in inflammatory bowel disease. J Intern Med (2012) 271(5):421-8. doi:10.1111/j.13652796.2012.02515.x

17. Söderholm JD, Olaison G, Peterson KH, Franzen LE, Lindmark T, Wiren M, et al. Augmented increase in tight junction permeability by luminal stimuli in the non-inflamed ileum of Crohn's disease. Gut (2002) 50(3):307-13. doi:10.1136/gut.50.3.307

18. Zeissig S, Burgel N, Gunzel D, Richter J, Mankertz J, Wahnschaffe U, et al. Changes in expression and distribution of claudin 2, 5 and 8 lead to discontinuous tight junctions and barrier dysfunction in active Crohn's disease. Gut (2007) 56(1):61-72. doi:10.1136/gut.2006.094375

19. Charriere G, Cousin B, Arnaud E, Andre M, Bacou F, Penicaud L, et al. Preadipocyte conversion to macrophage. Evidence of plasticity. J Biol Chem (2003) 278(11):9850-5. doi:10.1074/jbc.M210811200

20. Stroh T, Batra A, Glauben R, Fedke I, Erben U, Kroesen A, et al. Nucleotide oligomerization domains 1 and 2: regulation of expression and function in preadipocytes. J Immunol (2008) 181(5):3620-7.

21. Pietsch J, Batra A, Stroh T, Fedke I, Glauben R, Okur B, et al. Toll-like receptor expression and response to specific stimulation in adipocytes and preadipocytes: on the role of fat in inflammation. Ann N Y Acad Sci (2006) 1072:407-9. doi:10.1196/annals.1326.021

22. Spitzer JA, Kovach AG, Rosell S, Sandor P, Spitzer JJ, Storck R. Influence of endotoxin on adipose tissue metabolism. Adv Exp Med Biol (1972) 33(0): $337-44$.

23. Spitzer JA, Kovach AG, Sandor P, Spitzer JJ, Storck R. Adipose tissue and endotoxin shock. Acta Physiol Acad Sci Hung (1973) 44(2):183-93.

24. Sugawara K, Miyata G, Shineha R, Satomi S. The lipolytic responsiveness to endotoxin in subcutaneous adipose tissue is greater than mesenteric adipose tissue. Tohoku J Exp Med (2003) 199(3):171-9. doi:10.1620/tjem.199.171

25. Bagby GJ, Spitzer JA. Lipoprotein lipase activity in rat heart and adipose tissue during endotoxic shock. Am J Physiol (1980) 238(3):H325-30.

26. Hikawyj-Yevich I, Spitzer JA. Endotoxin influence on lipolysis in isolated human and primate adipocytes. J Surg Res (1977) 23(2):106-13. doi:10.1016/ 0022-4804(77)90197-4

27. Pond CM, Mattacks CA. In vivo evidence for the involvement of the adipose tissue surrounding lymph nodes in immune responses. Immunol Lett (1998) 63(3):159-67. doi:10.1016/S0165-2478(98)00074-1

28. Pond CM, Mattacks CA. Interactions between adipose tissue around lymph nodes and lymphoid cells in vitro. J Lipid Res (1995) 36(10):2219-31.

29. Lin Y, Lee H, Berg AH, Lisanti MP, Shapiro L, Scherer PE. The lipopolysaccharide-activated toll-like receptor (TLR)-4 induces synthesis of the closely related receptor TLR-2 in adipocytes. J Biol Chem (2000) 275(32):24255-63. doi:10.1074/jbc.M002137200

30. Sasai M, Yamamoto M. Pathogen recognition receptors: ligands and signaling pathways by toll-like receptors. Int Rev Immunol (2013) 32(2):116-33. doi:10.3109/08830185.2013.774391

31. Kawai T, Akira S. The role of pattern-recognition receptors in innate immunity: update on toll-like receptors. Nat Immunol (2010) 11(5):373-84. doi:10.1038/ ni. 1863

32. Bortoluci KR, Medzhitov R. Control of infection by pyroptosis and autophagy: role of TLR and NLR. Cell Mol Life Sci (2010) 67(10):1643-51. doi:10.1007/ s00018-010-0335-5

33. Kopp EB, Medzhitov R. The toll-receptor family and control of innate immunity. Curr Opin Immunol (1999) 11(1):13-8. doi:10.1016/S0952-7915(99) 80003-X

34. Brenner C, Simmonds RE, Wood S, Rose V, Feldmann M, Turner J. TLR signalling and adapter utilization in primary human in vitro differentiated adipocytes. Scand J Immunol (2012) 76(4):359-70. doi:10.1111/j.1365-3083. 2012.02744.x

35. Batra A, Pietsch J, Fedke I, Glauben R, Okur B, Stroh T, et al. Leptindependent toll-like receptor expression and responsiveness in preadipocytes and adipocytes. Am J Pathol (2007) 170(6):1931-41. doi:10.2353/ajpath.2007. 060699

36. Kopp A, Buechler C, Neumeier M, Weigert J, Aslanidis C, Scholmerich J, et al. Innate immunity and adipocyte function: ligand-specific activation of multiple toll-like receptors modulates cytokine, adipokine, and chemokine secretion in adipocytes. Obesity (Silver Spring) (2009) 17(4):648-56. doi:10.1038/oby.2008. 607

37. Kim SJ, Choi Y, Choi YH, Park T. Obesity activates toll-like receptor-mediated proinflammatory signaling cascades in the adipose tissue of mice. J Nutr Biochem (2010) 23(2):113-22. doi:10.1016/j.jnutbio.2010.10.012

38. Jaedicke KM, Roythorne A, Padget K, Todryk S, Preshaw PM, Taylor JJ. Leptin up-regulates TLR2 in human monocytes. J Leukoc Biol (2012) 93(4):561-71. doi:10.1189/jlb.1211606

39. Yoshida H, Watanabe W, Oomagari H, Tsuruta E, Shida M, Kurokawa M. Citrus flavonoid naringenin inhibits TLR2 expression in adipocytes. J Nutr Biochem (2013) 24(7):1276-84. doi:10.1016/j.jnutbio.2012.10.003

40. Schaeffler A, Gross P, Buettner R, Bollheimer C, Buechler C, Neumeier M, et al. Fatty acid-induced induction of toll-like receptor-4/nuclear factor-kappaB pathway in adipocytes links nutritional signalling with innate immunity. Immunology (2009) 126(2):233-45. doi:10.1111/j.1365-2567.2008.02892.x

41. Erridge C, Samani NJ. Saturated fatty acids do not directly stimulate tolllike receptor signaling. Arterioscler Thromb Vasc Biol (2009) 29(11):1944-9. doi:10.1161/ATVBAHA.109.194050

42. Murumalla RK, Gunasekaran MK, Padhan JK, Bencharif K, Gence L, Festy F, et al. Fatty acids do not pay the toll: effect of SFA and PUFA on human adipose tissue and mature adipocytes inflammation. Lipids Health Dis (2012) 11:175. doi:10.1186/1476-511X-11-175

43. Betanzos-Cabrera G, Estrada-Luna D, Belefant-Miller H, Cancino-Diaz JC. Mice fed with a high fat diet show a decrease in the expression of "toll like receptor (TLR) 2 and TLR6 mRNAs in adipose and hepatic tissues. Nutr Hosp (2012) 27(4):1196-203. doi:10.3305/nh.2012.27.4.5842

44. Franchi L, Warner N, Viani K, Nunez G. Function of Nod-like receptors in microbial recognition and host defense. Immunol Rev (2009) 227(1):106-28. doi:10.1111/j.1600-065X.2008.00734.x

45. Inohara N, Koseki T, del Peso L, Hu Y, Yee C, Chen S, et al. Nod1, an Apaf1-like activator of caspase-9 and nuclear factor-kappaB. J Biol Chem (1999) 274(21):14560-7. doi:10.1074/jbc.274.21.14560

46. Ogura Y, Inohara N, Benito A, Chen FF, Yamaoka S, Nunez G. Nod2, a Nod1/Apaf-1 family member that is restricted to monocytes and activates NFkappaB. J Biol Chem (2001) 276(7):4812-8. doi:10.1074/jbc.M008072200

47. Ogura Y, Bonen DK, Inohara N, Nicolae DL, Chen FF, Ramos R, et al. A frameshift mutation in NOD2 associated with susceptibility to Crohn's disease. Nature (2001) 411(6837):603-6. doi:10.1038/35079114

48. Hugot JP, Chamaillard M, Zouali H, Lesage S, Cezard JP, Belaiche J, et al. Association of NOD2 leucine-rich repeat variants with susceptibility to Crohn's disease. Nature (2001) 411(6837):599-603. doi:10.1038/35079107

49. Zhou YJ, Zhou H, Li Y, Song YL. NOD1 activation induces innate immune responses and insulin resistance in human adipocytes. Diabetes Metab (2011) 38(6):538-43. doi:10.1016/j.diabet.2012.08.001

50. Zhao L, Hu P, Zhou Y, Purohit J, Hwang D. NOD1 activation induces proinflammatory gene expression and insulin resistance in 3T3-L1 adipocytes. Am J Physiol Endocrinol Metab (2011) 301(4):E587-98. doi:10.1152/ajpendo.00709.2010

51. Purohit J, Hu P, Burke SJ, Collier JJ, Chen J, Zhao L. The effects of NOD activation on adipocyte differentiation. Obesity (Silver Spring) (2012). doi:10.1038/ oby. 2012.155

52. Tanabe T, Chamaillard M, Ogura Y, Zhu L, Qiu S, Masumoto J, et al. Regulatory regions and critical residues of NOD2 involved in muramyl dipeptide recognition. EMBO J (2004) 23(7):1587-97. doi:10.1038/sj.emboj.7600175

53. Brain O, Owens BM, Pichulik T, Allan P, Khatamzas E, Leslie A, et al. The intracellular sensor NOD2 induces microRNA-29 expression in human dendritic cells to limit IL-23 release. Immunity (2013) 39(3):521-36. doi:10.1016/ j.immuni.2013.08.035

54. Gutierrez A, Scharl M, Sempere L, Holler E, Zapater P, Almenta I, et al. Genetic susceptibility to increased bacterial translocation influences the response to biological therapy in patients with Crohn's disease. Gut (2013). doi:10.1136/ gutjnl-2012-303557

55. Weisberg SP, McCann D, Desai M, Rosenbaum M, Leibel RL, Ferrante AW Jr. Obesity is associated with macrophage accumulation in adipose tissue. J Clin Invest (2003) 112(12):1796-808. doi:10.1172/JCI19246

56. Xu H, Barnes GT, Yang Q, Tan G, Yang D, Chou CJ, et al. Chronic inflammation in fat plays a crucial role in the development of obesity-related insulin resistance. J Clin Invest (2003) 112(12):1821-30. doi:10.1172/JCI19451 
57. Cancello R, Henegar C, Viguerie N, Taleb S, Poitou C, Rouault C, et al. Reduction of macrophage infiltration and chemoattractant gene expression changes in white adipose tissue of morbidly obese subjects after surgery-induced weight loss. Diabetes (2005) 54(8):2277-86. doi:10.2337/diabetes.54.8.2277

58. Curat CA, Wegner V, Sengenes C, Miranville A, Tonus C, Busse R, et al. Macrophages in human visceral adipose tissue: increased accumulation in obesity and a source of resistin and visfatin. Diabetologia (2006) 49(4):744-7. doi:10.1007/s00125-006-0173-z

59. Desreumaux P, Ernst O, Geboes K, Gambiez L, Berrebi D, Muller-Alouf $\mathrm{H}$, et al. Inflammatory alterations in mesenteric adipose tissue in Crohn's disease. Gastroenterology (1999) 117(1):73-81. doi:10.1016/S0016-5085(99) 70552-4

60. Koon HW, Kim YS, Xu H, Kumar A, Zhao D, Karagiannides I, et al. Neurotensin induces IL-6 secretion in mouse preadipocytes and adipose tissues during 2,4,6,-trinitrobenzensulphonic acid-induced colitis. Proc Natl Acad Sci U S A (2009) 106(21):8766-71. doi:10.1073/pnas.0903499106

61. Karagiannides I, Kokkotou E, Tansky M, Tchkonia T, Giorgadze N, O’Brien M, et al. Induction of colitis causes inflammatory responses in fat depots: evidence for substance P pathways in human mesenteric preadipocytes. Proc Natl Acad Sci U S A (2006) 103(13):5207-12. doi:10.1073/pnas.0600821103

62. Chung S, Lapoint K, Martinez K, Kennedy A, Boysen Sandberg M, McIntosh MK. Preadipocytes mediate lipopolysaccharide-induced inflammation and insulin resistance in primary cultures of newly differentiated human adipocytes. Endocrinology (2006) 147(11):5340-51. doi:10.1210/en. 2006-0536

63. Creely SJ, McTernan PG, Kusminski CM, Fisher FM, Da Silva NF, Khanolkar $\mathrm{M}$, et al. Lipopolysaccharide activates an innate immune system response in human adipose tissue in obesity and type 2 diabetes. Am J Physiol Endocrinol Metab (2007) 292(3):E740-7. doi:10.1152/ajpendo.00302.2006

64. Poulain-Godefroy O, Froguel P. Preadipocyte response and impairment of differentiation in an inflammatory environment. Biochem Biophys Res Commun (2007) 356(3):662-7. doi:10.1016/j.bbrc.2007.03.053

65. Barbier M, Vidal H, Desreumaux P, Dubuquoy L, Bourreille A, Colombel JF, et al. Overexpression of leptin mRNA in mesenteric adipose tissue in inflammatory bowel diseases. Gastroenterol Clin Biol (2003) 27(11):987-91.

66. Schaffler A, Furst A, Buchler C, Paul G, Rogler G, Scholmerich J, et al. Secretion of RANTES (CCL5) and interleukin-10 from mesenteric adipose tissue and from creeping fat in Crohn's disease: regulation by steroid treatment. J Gastroenterol Hepatol (2006) 21(9):1412-8. doi:10.1111/j.1440-1746.2006. 04300.x

67. Paul G, Schaffler A, Neumeier M, Furst A, Bataillle F, Buechler C, et al. Profiling adipocytokine secretion from creeping fat in Crohn's disease. Inflamm Bowel Dis (2006) 12(6):471-7. doi:10.1097/00054725-200606000-00005

68. Gordon S, Martinez FO. Alternative activation of macrophages: mechanism and functions. Immunity (2010) 32(5):593-604. doi:10.1016/j.immuni.2010. 05.007

69. Gordon S, Taylor PR. Monocyte and macrophage heterogeneity. Nat Rev Immunol (2005) 5(12):953-64. doi:10.1038/nri1733

70. Mantovani A, Sica A, Sozzani S, Allavena P, Vecchi A, Locati M. The chemokine system in diverse forms of macrophage activation and polarization. Trends Immunol (2004) 25(12):677-86. doi:10.1016/j.it.2004.09.015

71. Cinti S, Mitchell G, Barbatelli G, Murano I, Ceresi E, Faloia E, et al. Adipocyte death defines macrophage localization and function in adipose tissue of obese mice and humans. J Lipid Res (2005) 46(11):2347-55. doi:10.1194/jlr. M500294-JLR200

72. Zeyda M, Farmer D, Todoric J, Aszmann O, Speiser M, Gyori G, et al. Human adipose tissue macrophages are of an anti-inflammatory phenotype but capable of excessive pro-inflammatory mediator production. Int J Obes (Lond) (2007) 31(9):1420-8. doi:10.1038/sj.ijo.0803632

73. Lumeng CN, Bodzin JL, Saltiel AR. Obesity induces a phenotypic switch in adipose tissue macrophage polarization. J Clin Invest (2007) 117(1):175-84. doi:10.1172/JCI29881

74. Lumeng CN, Deyoung SM, Bodzin JL, Saltiel AR. Increased inflammatory properties of adipose tissue macrophages recruited during diet-induced obesity. Diabetes (2007) 56(1):16-23. doi:10.2337/db06-1076

75. Kredel LI, Batra A, Stroh T, Kuhl AA, Zeitz M, Erben U, et al. Adipokines from local fat cells shape the macrophage compartment of the creeping fat in Crohn's disease. Gut (2012) 62(6):852-62. doi:10.1136/gutjnl-2011-301424
76. Mudter J, Neurath MF. Il-6 signaling in inflammatory bowel disease: pathophysiological role and clinical relevance. Inflamm Bowel Dis (2007) 13(8):1016-23. doi:10.1002/ibd.20148

77. Mohamed-Ali V, Pinkney JH, Coppack SW. Adipose tissue as an endocrine and paracrine organ. Int J Obes Relat Metab Disord (1998) 22(12):1145-58. doi:10.1038/sj.ijo.0800770

78. van Deventer SJ. Review article: targeting TNF alpha as a key cytokine in the inflammatory processes of Crohn's disease - the mechanisms of action of infliximab. Aliment Pharmacol Ther (1999) 13(Suppl 4):3-8. doi:10.1046/j. 1365-2036.1999.00024.x

79. Hanauer SB, Feagan BG, Lichtenstein GR, Mayer LF, Schreiber S, Colombel JF, et al. Maintenance infliximab for Crohn's disease: the ACCENT I randomised trial. Lancet (2002) 359(9317):1541-9. doi:10.1016/S0140-6736(02)08512-4

80. Hanauer SB, Sandborn WJ, Rutgeerts P, Fedorak RN, Lukas M, MacIntosh $\mathrm{D}$, et al. Human anti-tumor necrosis factor monoclonal antibody (adalimumab) in Crohn's disease: the CLASSIC-I trial. Gastroenterology (2006) 130(2):323-33. doi:10.1053/j.gastro.2005.11.030

81. Denmark VK, Mayer L. Current status of monoclonal antibody therapy for the treatment of inflammatory bowel disease: an update. Exp Rev Clin immunology (2013) 9(1):77-92. doi:10.1586/eci.12.91

82. Leal RF, Milanski M, Ayrizono Mde L, Coope A, Rodrigues VS, Portovedo M, et al. Toll-like receptor 4, F4/80 and pro-inflammatory cytokines in intestinal and mesenteric fat tissue of Crohn's disease. Int J Clin Exp Med (2013) 6(2):98-104.

83. Clahsen T, Schaper F. Interleukin-6 acts in the fashion of a classical chemokine on monocytic cells by inducing integrin activation, cell adhesion, actin polymerization, chemotaxis, and transmigration. J Leukoc Biol (2008) 84(6):1521-9. doi:10.1189/jlb.0308178

84. Romano M, Sironi M, Toniatti C, Polentarutti N, Fruscella P, Ghezzi P, et al. Role of IL- 6 and its soluble receptor in induction of chemokines and leukocyte recruitment. Immunity (1997) 6(3):315-25. doi:10.1016/S1074-7613(00) 80334-9

85. Kaplanski G, Marin V, Montero-Julian F, Mantovani A, Farnarier C. IL-6: a regulator of the transition from neutrophil to monocyte recruitment during inflammation. Trends Immunol (2003) 24(1):25-9. doi:10.1016/S14714906(02)00013-3

86. Fasshauer M, Kralisch S, Klier M, Lossner U, Bluher M, Klein J, et al. Adiponectin gene expression and secretion is inhibited by interleukin- 6 in 3T3-L1 adipocytes. Biochem Biophys Res Commun (2003) 301(4):1045-50. doi:10.1016/S0006-291X(03)00090- 1

87. Bruun JM, Lihn AS, Verdich C, Pedersen SB, Toubro S, Astrup A, et al. Regulation of adiponectin by adipose tissue-derived cytokines: in vivo and in vitro investigations in humans. Am J Physiol Endocrinol Metab (2003) 285(3):E527-33. doi:10.1152/ajpendo.00110.200300110.2003

88. Simons PJ, van den Pangaart PS, van Roomen CP, Aerts JM, Boon L. Cytokinemediated modulation of leptin and adiponectin secretion during in vitro adipogenesis: evidence that tumor necrosis factor-alpha- and interleukin-1betatreated human preadipocytes are potent leptin producers. Cytokine (2005) 32(2):94-103. doi:10.1016/j.cyto.2005.08.003

89. Pamir N, McMillen TS, Kaiyala KJ, Schwartz MW, LeBoeuf RC. Receptors for tumor necrosis factor-alpha play a protective role against obesity and alter adipose tissue macrophage status. Endocrinology (2009) 150(9):4124-34. doi:10.1210/en.2009-0137

90. Vos AC, Wildenberg ME, Duijvestein M, Verhaar AP, van den Brink GR, Hommes DW. Anti-tumor necrosis factor-alpha antibodies induce regulatory macrophages in an Fc region-dependent manner. Gastroenterology (2011) 140(1):221-30. doi:10.1053/j.gastro.2010.10.008

91. Henriksen M, Jahnsen J, Lygren I, Stray N, Sauar J, Vatn MH, et al. C-reactive protein: a predictive factor and marker of inflammation in inflammatory bowel disease. Results from a prospective population-based study. Gut (2008) 57(11):1518-23. doi:10.1136/gut.2007.146357

92. Du Clos TW. Pentraxins: structure, function, and role in inflammation. ISRN Inflamm (2013) 2013:379040. doi:10.1155/2013/379040

93. Anty R, Bekri S, Luciani N, Saint-Paul MC, Dahman M, Iannelli A, et al. The inflammatory C-reactive protein is increased in both liver and adipose tissue in severely obese patients independently from metabolic syndrome, type 2 diabetes, and NASH. Am J Gastroenterol (2006) 101(8):1824-33. doi:10.1111/j.1572-0241.2006.00724.x 
94. Ballou SP, Lozanski G. Induction of inflammatory cytokine release from cultured human monocytes by C-reactive protein. Cytokine (1992) 4(5):361-8. doi:10.1016/1043-4666(92)90079-7

95. Pue CA, Mortensen RF, Marsh CB, Pope HA, Wewers MD. Acute phase levels of C-reactive protein enhance IL-1 beta and IL-1ra production by human blood monocytes but inhibit IL-1 beta and IL-1ra production by alveolar macrophages. J Immunol (1996) 156(4):1594-600.

96. Tilg H, Vannier E, Vachino G, Dinarello CA, Mier JW. Antiinflammatory properties of hepatic acute phase proteins: preferential induction of interleukin 1 (IL-1) receptor antagonist over IL-1 beta synthesis by human peripheral blood mononuclear cells. J Exp Med (1993) 178(5):1629-36. doi:10.1084/jem.178.5. 1629

97. Galve-de Rochemonteix B, Wiktorowicz K, Kushner I, Dayer JM. C-reactive protein increases production of IL-1 alpha, IL-1 beta, and TNF-alpha, and expression of mRNA by human alveolar macrophages. J Leukoc Biol (1993) 53(4):439-45.

98. Singh U, Devaraj S, Dasu MR, Ciobanu D, Reusch J, Jialal I. C-reactive protein decreases interleukin-10 secretion in activated human monocyte-derived macrophages via inhibition of cyclic AMP production. Arterioscler Thromb Vasc Biol (2006) 26(11):2469-75. doi:10.1161/01.ATV.0000241572.05292.fb

99. Mold C, Rodriguez W, Rodic-Polic B, Du Clos TW. C-reactive protein mediates protection from lipopolysaccharide through interactions with Fc gamma R. J Immunol (2002) 169(12):7019-25.

100. Devaraj S, Jialal I. C-reactive protein polarizes human macrophages to an M1 phenotype and inhibits transformation to the M2 phenotype. Arterioscler Thromb Vasc Biol (2011) 31(6):1397-402. doi:10.1161/ATVBAHA.111.225508

101. Devaraj S, Yun JM, Duncan-Staley C, Jialal I. C-reactive protein induces MCSF release and macrophage proliferation. J Leukoc Biol (2009) 85(2):262-7. doi:10.1189/jlb.0808458

102. Christiansen T, Richelsen B, Bruun JM. Monocyte chemoattractant protein-1 is produced in isolated adipocytes, associated with adiposity and reduced after weight loss in morbid obese subjects. Int J Obes (Lond) (2005) 29(1):146-50. doi:10.1038/sj.ijo.0802839

103. Gunn MD, Nelken NA, Liao X, Williams LT. Monocyte chemoattractant protein-1 is sufficient for the chemotaxis of monocytes and lymphocytes in transgenic mice but requires an additional stimulus for inflammatory activation. J Immunol (1997) 158(1):376-83.

104. Lu B, Rutledge BJ, Gu L, Fiorillo J, Lukacs NW, Kunkel SL, et al. Abnormalities in monocyte recruitment and cytokine expression in monocyte chemoattractant protein 1-deficient mice. J Exp Med (1998) 187(4):601-8. doi:10.1084/jem.187.4.601

105. Kanda H, Tateya S, Tamori Y, Kotani K, Hiasa K, Kitazawa R, et al. MCP1 contributes to macrophage infiltration into adipose tissue, insulin resistance, and hepatic steatosis in obesity. J Clin Invest (2006) 116(6):1494-505. doi:10.1172/JCI26498

106. Weisberg SP, Hunter D, Huber R, Lemieux J, Slaymaker S, Vaddi K, et al. CCR2 modulates inflammatory and metabolic effects of high-fat feeding. J Clin Invest (2006) 116(1):115-24. doi:10.1172/JCI24335C1

107. Kamei N, Tobe K, Suzuki R, Ohsugi M, Watanabe T, Kubota N, et al. Overexpression of monocyte chemoattractant protein-1 in adipose tissues causes macrophage recruitment and insulin resistance. J Biol Chem (2006) 281(36):26602-14. doi:10.1074/jbc.M601284200

108. Inouye KE, Shi H, Howard JK, Daly CH, Lord GM, Rollins BJ, et al. Absence of CC chemokine ligand 2 does not limit obesity-associated infiltration of macrophages into adipose tissue. Diabetes (2007) 56(9):2242-50. doi:10.2337/ db07-0425

109. Kirk EA, Sagawa ZK, McDonald TO, O’Brien KD, Heinecke JW. Monocyte chemoattractant protein deficiency fails to restrain macrophage infiltration into adipose tissue [corrected]. Diabetes (2008) 57(5):1254-61. doi:10.2337/ db07-1061

110. Fridlender ZG, Kapoor V, Buchlis G, Cheng G, Sun J, Wang LC, et al. Monocyte chemoattractant protein-1 blockade inhibits lung cancer tumor growth by altering macrophage phenotype and activating CD8+ cells. Am J Respir Cell Mol Biol (2011) 44(2):230-7. doi:10.1165/rcmb.2010-0080OC

111. Roca H, Varsos ZS, Sud S, Craig MJ, Ying C, Pienta KJ. CCL2 and interleukin6 promote survival of human $\mathrm{CD} 1 \mathrm{lb}+$ peripheral blood mononuclear cells and induce M2-type macrophage polarization. J Biol Chem (2009) 284(49):34342-54. doi:10.1074/jbc.M109.042671

112. Kitade H, Sawamoto K, Nagashimada M, Inoue H, Yamamoto Y, Sai Y, et al. CCR5 plays a critical role in obesity-induced adipose tissue inflammation and insulin resistance by regulating both macrophage recruitment and M1/M2 status. Diabetes (2012) 61(7):1680-90. doi:10.2337/db11-1506

113. Levine JA, Jensen MD, Eberhardt NL, O’Brien T. Adipocyte macrophage colony-stimulating factor is a mediator of adipose tissue growth. J Clin Invest (1998) 101(8):1557-64. doi:10.1172/JCI2293

114. Wiktor-Jedrzejczak W, Urbanowska E, Aukerman SL, Pollard JW, Stanley ER, Ralph P, et al. Correction by CSF-1 of defects in the osteopetrotic op/op mouse suggests local, developmental, and humoral requirements for this growth factor. Exp Hematol (1991) 19(10):1049-54.

115. Verreck FA, de Boer T, Langenberg DM, Hoeve MA, Kramer M, Vaisberg E, et al. Human IL-23-producing type 1 macrophages promote but IL-10-producing type 2 macrophages subvert immunity to (myco)bacteria. Proc Natl Acad Sci U $S$ A (2004) 101(13):4560-5. doi:10.1073/pnas.0400983101

116. Verreck FA, de Boer T, Langenberg DM, van der Zanden L, Ottenhoff TH. Phenotypic and functional profiling of human proinflammatory type- 1 and anti-inflammatory type-2 macrophages in response to microbial antigens and IFN-gamma- and CD40L-mediated costimulation. J Leukoc Biol (2006) 79(2):285-93. doi:10.1189/jlb.0105015

117. Fleetwood AJ, Lawrence T, Hamilton JA, Cook AD. Granulocyte-macrophage colony-stimulating factor (CSF) and macrophage CSF-dependent macrophage phenotypes display differences in cytokine profiles and transcription factor activities: implications for CSF blockade in inflammation. J Immunol (2007) 178(8):5245-52.

118. Fleetwood AJ, Dinh H, Cook AD, Hertzog PJ, Hamilton JA. GM-CSF- and MCSF-dependent macrophage phenotypes display differential dependence on type I interferon signaling. J Leukoc Biol (2009) 86(2):411-21. doi:10.1189/jlb. 1108702

119. Willman CL, Stewart CC, Miller V, Yi TL, Tomasi TB. Regulation of MHC class II gene expression in macrophages by hematopoietic colony-stimulating factors (CSF). Induction by granulocyte/macrophage CSF and inhibition by CSF-1. J Exp Med (1989) 170(5):1559-67. doi:10.1084/jem.170.5.1559

120. Phillips WA, Hamilton JA. Colony stimulating factor-1 is a negative regulator of the macrophage respiratory burst. J Cell Physiol (1990) 144(2):190-6. doi:10.1002/jcp.1041440203

121. Kim DH, Sandoval D, Reed JA, Matter EK, Tolod EG, Woods SC, et al. The role of GM-CSF in adipose tissue inflammation. Am J Physiol Endocrinol Metab (2008) 295(5):E1038-46. doi:10.1152/ajpendo.00061.2008

122. El Homsi M, Ducroc R, Claustre J, Jourdan G, Gertler A, Estienne M, et al. Leptin modulates the expression of secreted and membrane-associated mucins in colonic epithelial cells by targeting PKC, PI3K, and MAPK pathways. Am J Physiol Gastrointest Liver Physiol (2007) 293(1):G365-73. doi:10.1152/ajpgi. 00091.2007

123. Le Drean G, Haure-Mirande V, Ferrier L, Bonnet C, Hulin P, de Coppet P, et al. Visceral adipose tissue and leptin increase colonic epithelial tight junction permeability via a RhoA-ROCK-dependent pathway. FASEB J (2013). doi:10.1096/fj.13-234203

124. Plaisancie P, Ducroc R, El Homsi M, Tsocas A, Guilmeau S, Zoghbi S, et al. Luminal leptin activates mucin-secreting goblet cells in the large bowel. Am J Physiol Gastrointest Liver Physiol (2006) 290(4):G805-12. doi:10.1152/ajpgi. 00433.2005

125. Hardwick JC, van den Brink GR, Offerhaus GJ, Van Deventer SJ, Peppelenbosch MP. Leptin is a growth factor for colonic epithelial cells. Gastroenterology (2001) 121(1):79-90. doi:10.1053/gast.2001.25490

126. Amar J, Chabo C, Waget A, Klopp P, Vachoux C, Bermudez-Humaran LG, et al. Intestinal mucosal adherence and translocation of commensal bacteria at the early onset of type 2 diabetes: molecular mechanisms and probiotic treatment. EMBO Mol Med (2011) 3(9):559-72. doi:10.1002/emmm.201100159

127. Loffreda S, Yang SQ, Lin HZ, Karp CL, Brengman ML, Wang DJ, et al. Leptin regulates proinflammatory immune responses. FASEB J (1998) 12(1):57-65.

128. Gainsford T, Willson TA, Metcalf D, Handman E, McFarlane C, Ng A, et al. Leptin can induce proliferation, differentiation, and functional activation of hemopoietic cells. Proc Natl Acad Sci U S A (1996) 93(25):14564-8. doi:10.1073/pnas.93.25.14564

129. Sanchez-Pozo C, Rodriguez-Bano J, Dominguez-Castellano A, Muniain MA, Goberna R, Sanchez-Margalet V. Leptin stimulates the oxidative burst in control monocytes but attenuates the oxidative burst in monocytes from HIVinfected patients. Clin Exp Immunol (2003) 134(3):464-9. doi:10.1111/j.13652249.2003.02321.x

130. Curat CA, Miranville A, Sengenes C, Diehl M, Tonus C, Busse R, et al. From blood monocytes to adipose tissue-resident macrophages: induction 
of diapedesis by human mature adipocytes. Diabetes (2004) 53(5):1285-92. doi:10.2337/diabetes.53.5.1285

131. Acedo SC, Gambero S, Cunha FG, Lorand-Metze I, Gambero A. Participation of leptin in the determination of the macrophage phenotype: an additional role in adipocyte and macrophage crosstalk. In vitro Cell Dev Biol Anim (2013) 49(6):473-8. doi:10.1007/s11626-013-9629-x

132. Shapiro L, Scherer PE. The crystal structure of a complement-1q family protein suggests an evolutionary link to tumor necrosis factor. Curr Biol (1998) 8(6):335-8. doi:10.1016/S0960-9822(98)70133-2

133. Kishore U, Gaboriaud C, Waters P, Shrive AK, Greenhough TJ, Reid KB, et al. $\mathrm{C} 1 \mathrm{q}$ and tumor necrosis factor superfamily: modularity and versatility. Trends Immunol (2004) 25(10):551-61. doi:10.1016/j.it.2004.08.006

134. Yamamoto K, Kiyohara T, Murayama $Y$, Kihara S, Okamoto Y, Funahashi $T$, et al. Production of adiponectin, an anti-inflammatory protein, in mesenteric adipose tissue in Crohn's disease. Gut (2005) 54(6):789-96. doi:10.1136/gut. 2004.046516

135. Yokota T, Oritani K, Takahashi I, Ishikawa J, Matsuyama A, Ouchi N, et al. Adiponectin, a new member of the family of soluble defense collagens, negatively regulates the growth of myelomonocytic progenitors and the functions of macrophages. Blood (2000) 96(5):1723-32.

136. Wulster-Radcliffe MC, Ajuwon KM, Wang J, Christian JA, Spurlock ME. Adiponectin differentially regulates cytokines in porcine macrophages. Biochem Biophys Res Commun (2004) 316(3):924-9. doi:10.1016/j.bbrc.2004. 02.130

137. Folco EJ, Rocha VZ, Lopez-Ilasaca M, Libby P. Adiponectin inhibits proinflammatory signaling in human macrophages independent of interleukin-10. J Biol Chem (2009) 284(38):25569-75. doi:10.1074/jbc.M109.019786

138. Ouchi N, Kihara S, Arita Y, Maeda K, Kuriyama H, Okamoto Y, et al. Novel modulator for endothelial adhesion molecules: adipocyte-derived plasma protein adiponectin. Circulation (1999) 100(25):2473-6. doi:10.1161/01.CIR.100. 25.2473

139. Ouchi N, Kihara S, Arita Y, Okamoto Y, Maeda K, Kuriyama H, et al. Adiponectin, an adipocyte-derived plasma protein, inhibits endothelial NFkappaB signaling through a cAMP-dependent pathway. Circulation (2000) 102(11):1296-301. doi:10.1161/01.CIR.102.11.1296

140. Lovren F, Pan Y, Quan A, Szmitko PE, Singh KK, Shukla PC, et al. Adiponectin primes human monocytes into alternative anti-inflammatory M2 macrophages. Am J Physiol Heart Circ Physiol (2010) 299(3):H656-63. doi:10.1152/ajpheart.00115.2010

141. Ohashi K, Parker JL, Ouchi N, Higuchi A, Vita JA, Gokce N, et al. Adiponectin promotes macrophage polarization toward an anti-inflammatory phenotype. J Biol Chem (2010) 285(9):6153-60. doi:10.1074/jbc.M109.088708

142. Mandal P, Pratt BT, Barnes M, McMullen MR, Nagy LE. Molecular mechanism for adiponectin-dependent M2 macrophage polarization: link between the metabolic and innate immune activity of full-length adiponectin. J Biol Chem (2011) 286(15):13460-9. doi:10.1074/jbc.M110.204644

143. Cheng X, Folco EJ, Shimizu K, Libby P. Adiponectin induces pro-inflammatory programs in human macrophages and CD4+ T cells. J Biol Chem (2012) 287(44):36896-904. doi:10.1074/jbc.M112.409516

144. Karmiris K, Koutroubakis IE, Xidakis C, Polychronaki M, Voudouri T, Kouroumalis EA. Circulating levels of leptin, adiponectin, resistin, and ghrelin in inflammatory bowel disease. Inflamm Bowel Dis (2006) 12(2):100-5. doi:10.1097/01.MIB.0000200345.38837.46

145. Valentini L, Wirth EK, Schweizer U, Hengstermann S, Schaper L, Koernicke $\mathrm{T}$, et al. Circulating adipokines and the protective effects of hyperinsulinemia in inflammatory bowel disease. Nutrition (2009) 25(2):172-81. doi:10.1016/j.nut.2008.07.020

146. Fain JN, Cheema PS, Bahouth SW, Lloyd Hiler M. Resistin release by human adipose tissue explants in primary culture. Biochem Biophys Res Commun (2003) 300(3):674-8. doi:10.1016/S0006-291X(02)02864-4

147. Patel L, Buckels AC, Kinghorn IJ, Murdock PR, Holbrook JD, Plumpton C, et al. Resistin is expressed in human macrophages and directly regulated by PPAR gamma activators. Biochem Biophys Res Commun (2003) 300(2):472-6. doi:10.1016/S0006-291X(02)02841-3

148. Kaser S, Kaser A, Sandhofer A, Ebenbichler CF, Tilg H, Patsch JR. Resistin messenger-RNA expression is increased by proinflammatory cytokines in vitro. Biochem Biophys Res Commun (2003) 309(2):286-90. doi:10.1016/j.bbrc.2003. 07.003
149. Lehrke M, Reilly MP, Millington SC, Iqbal N, Rader DJ, Lazar MA. An inflammatory cascade leading to hyperresistinemia in humans. PLoS Med (2004) 1(2):e45. doi:10.1371/journal.pmed.0010045

150. Kusminski CM, da Silva NF, Creely SJ, Fisher FM, Harte AL, Baker AR, et al. The in vitro effects of resistin on the innate immune signaling pathway in isolated human subcutaneous adipocytes. JClin Endocrinol Metab (2007) 92(1):270-6. doi:10.1210/jc.2006-1151

151. Bokarewa M, Nagaev I, Dahlberg L, Smith U, Tarkowski A. Resistin, an adipokine with potent proinflammatory properties. J Immunol (2005) 174(9):5789-95.

152. Silswal N, Singh AK, Aruna B, Mukhopadhyay S, Ghosh S, Ehtesham NZ. Human resistin stimulates the pro-inflammatory cytokines TNF-alpha and IL12 in macrophages by NF-kappaB-dependent pathway. Biochem Biophys Res Commun (2005) 334(4):1092-101. doi:10.1016/j.bbrc.2005.06.202

153. Verma S, Li SH, Wang CH, Fedak PW, Li RK, Weisel RD, et al. Resistin promotes endothelial cell activation: further evidence of adipokine-endothelial interaction. Circulation (2003) 108(6):736-40. doi:10.1161/01.CIR.0000084503. 91330.49

154. Fukuhara A, Matsuda M, Nishizawa M, Segawa K, Tanaka M, Kishimoto K, et al. Visfatin: a protein secreted by visceral fat that mimics the effects of insulin. Science (2005) 307(5708):426-30. doi:10.1126/science.1097243

155. Moschen AR, Kaser A, Enrich B, Mosheimer B, Theurl M, Niederegger H, et al. Visfatin, an adipocytokine with proinflammatory and immunomodulating properties. J Immunol (2007) 178(3):1748-58.

156. Moschen AR, Geiger S, Gerner R, Tilg H. Pre-B cell colony enhancing factor/NAMPT/visfatin and its role in inflammation-related bone disease. Mutat Res (2010) 690(1-2):95-101. doi:10.1016/j.mrfmmm.2009.06.012

157. Ye SQ, Simon BA, Maloney JP, Zambelli-Weiner A, Gao L, Grant A, et al. PreB-cell colony-enhancing factor as a potential novel biomarker in acute lung injury. Am J Respir Crit Care Med (2005) 171(4):361-70. doi:10.1164/rccm. 200404-563OC

158. Dahl TB, Yndestad A, Skjelland M, Oie E, Dahl A, Michelsen A, et al. Increased expression of visfatin in macrophages of human unstable carotid and coronary atherosclerosis: possible role in inflammation and plaque destabilization. $\mathrm{Cir}$ culation (2007) 115(8):972-80. doi:10.1161/CIRCULATIONAHA.106.665893

159. Brentano F, Schorr O, Ospelt C, Stanczyk J, Gay RE, Gay S, et al. Pre-B cell colony-enhancing factor/visfatin, a new marker of inflammation in rheumatoid arthritis with proinflammatory and matrix-degrading activities. Arthritis Rheum (2007) 56(9):2829-39. doi:10.1002/art.22833

160. Kang YS, Kang YG, Park HJ, Wee HJ, Jang HO, Bae MK, et al. Melatonin inhibits visfatin-induced inducible nitric oxide synthase expression and nitric oxide production in macrophages. J Pineal Res (2013) 55(3):294-303. doi:10.1111/jpi.12072

161. Pal D, Dasgupta S, Kundu R, Maitra S, Das G, Mukhopadhyay S, et al. FetuinA acts as an endogenous ligand of TLR4 to promote lipid-induced insulin resistance. Nat Med (2012) 18(8):1279-85. doi:10.1038/nm.2851

162. Chatterjee P, Seal S, Mukherjee S, Kundu R, Ray S, Mukhopadhyay S, et al. Adipocyte fetuin-a contributes to macrophage migration into adipose tissue and polarization of macrophages. J Biol Chem (2013) 288(39):28324-30. doi:10.1074/jbc.C113.495473

Conflict of Interest Statement: The authors declare that the research was conducted in the absence of any commercial or financial relationships that could be construed as a potential conflict of interest.

Received: 31 October 2013; paper pending published: 27 November 2013; accepted: 24 December 2013; published online: 06 January 2014.

Citation: Kruis T, Batra A and Siegmund B (2014) Bacterial translocation-impact on the adipocyte compartment. Front. Immunol. 4:510. doi: 10.3389/fimmu.2013.00510 This article was submitted to Inflammation, a section of the journal Frontiers in Immunology.

Copyright $\odot 2014$ Kruis, Batra and Siegmund. This is an open-access article distributed under the terms of the Creative Commons Attribution License (CC BY). The use, distribution or reproduction in other forums is permitted, provided the original author $(s)$ or licensor are credited and that the original publication in this journal is cited, in accordance with accepted academic practice. No use, distribution or reproduction is permitted which does not comply with these terms. 